\title{
НАЦІОНАЛЬНО-КУЛЬТУРНА СПЕЦИФІКА НОМЕНКЛАТУРНИХ ЗНАКІВ (НОМЕНІВ) НА ПОЗНАЧЕННЯ АВТОБУСНОЇ ТЕХНІКИ УКРАЇНСЬКОГО ВИРОБНИЦТВА
}

У пропонованій статті продовжено дослідження методології моделювання автотранспортного номена, здійснено спробу віднайти й виокремити із загального масиву номенклатури насамперед корпус відонімних моделей номенів, розглянути їхню етимологію й природу значення. Особлива увага закцентована на національно-культурній спещибіиі онімного складника номенклатурних знаків (номенів) на позначення автобусної техніки українського виробника. Заналізовано й схарактеризовано автобусні номени з позицій широкого трактування номенклатурно-мислительних процесів як прагнення забіксувати в об'єкті культурологічні иінності соиіуму.

Ключові слова: номенклатурний знак (номен), номенклатурне моделювання, онімний складник, автобус.

Nikulina N. National Cultural Specificity of Nomenclature Signs (Nomen) to Denote Ukrainian-Manufactured Buses. The article presents a further study of the methodology for modeling automotive nomenclature. An attempt to single out from the general array of nomenclature the body of models of nomens formed from onyms and to consider their etymology and nature of meaning is made. The relevance of the research is due to the growing interest to the issues of the national cultural specificity of the onym component of nomenclature signs to denote buses manufactured in Ukraine.

Methodological studies in the field of terminology, in particular, those the subject of which is a nomenclature sign to denote scientific and technical concepts related to motor vehicles, occupy a special place among the scientific problems considered by the author. Studies on the indicated topics using the material of modern names for Japanese brands, models and modifications of motor vehicles have already been carried out; nomenclature and nomination processes of naming and developing technical color nomens for automotive paints, based on secondary nomination and transonymization, have been characterized.

The purpose of the article is to analyze and characterize bus nomens from the perspective of a broad interpretation of nomenclature and thinking processes as the intention to fix the cultural values of society in an object. The objectives of the research are 1) to single out nomenclature signs to denote buses manufactured in Ukraine from a wide range of bus names; 2) to briefly describe the linguistic and cultural aspects of naming buses in Ukrainian and foreign nomination. 
A further research direction is to thoroughly study a number of relevant issues which concern 1) clarifying the type of the semantic component of motor transport nomens formed from onyms and the relationship of a person's associations and the denoted material object; 2) classifying motor transport nomens formed from appellatives and defining types of nomenclature modeling and varieties of the semantic component; 3) typologizing alphanumeric components of nomenclature units used to denote motor vehicles.

Key words: nomenclature sign (nomen), nomenclature modeling, onym component, bus.

\section{Вступ}

Методологічні дослідження в царині термінознавства неодноразово були серед опікуваних нами наукових проблем, зокрема йдеться про наукові розвідки, тематикою яких є номенклатурний знак на позначення автотранспортної науково-технічної реалії, адже технічний номен (техномен) є другим за значущістю різновидом спеціальної лексичної одиниці транспортної термінологічної мегасистеми. За вказаною тематикою вже проведено дослідження на матеріалі сучасних назв японських марок, моделей і модифікацій автотранспортних засобів, схарактеризовано номенклатурно-номінаційні процеси найменування й продукування технічних кольорономенів автомобільних фарб, в основу яких покладено засіб вторинної номінації та трансонімізації (Нікуліна, 2017; Нікуліна, 2018). Продовжуючи досліджувати методологію моделювання автотранспортного номена, у пропонованій статті розглянемо національно-культурну специфіку онімного складника номенів на позначення автобусної техніки українського виробництва, опрацюємо етимологію й природу значення відонімних моделей номенклатурних знаків.

Зацікавлення в мовознавстві номінаційними процесами в науково-технічній лексиці спричинене розвитком і розширенням підгалузей ономастики, їхнім впливом на суміжні галузі, зокрема й на термінознавство. Ономастичної лексики в теорії й практиці побіжно торкалися українські науковці, що досліджують прагматоніми й прагмоніми (О.О.Белей, Я. В. Браницька, О. В. Вінарєва, М. М. Дзюба, Г. В. Зимовець, О. Ю. Карпенко, М. А. Курушина, Т. Ю. Ковалевська, Н. В. Лиса, О. О. Приймак, О. М. Тепла, С. О. Шестакова, С. А. Яценко). Більш звужено, зокрема процеси номінації матеріальних об'єктів у галузі автомобілебудування, походження й семантику, типи мотиваційних 
відношень техноменів на позначення марок автомобілів, розглядали А. П. Романченко, Н. М. Хрустик, Г. Б. Фогель, А. М. Янчишин. Однак у межах українського й зарубіжного термінознавства нами не зафіксовано наукових робіт, де б досліджувалися номенклатурні знаки на позначення найменувань ще одного з найбільш поширених видів автотранспортної техніки - автобусів.

Метою пропонованої статті $€$ аналіз і характеристика автобусних номенів з позицій широкого трактування номенклатурно-мислительних процесів як прагнення зафіксувати в об’єкті культурологічні цінності соціуму.

Ця мета конкретизується в таких завданнях: 1) виокремити із широкого загалу найменувань автобусної техніки номенклатурні знаки на позначення автобусів українського виробництва; 2) стисло схарактеризувати лінгвокультурологічні аспекти номінування автобусної техніки в українському й зарубіжному назовництві.

\section{Методи й методики дослідження}

Для виконання окреслених у науковій розвідці завдань застосовано такі методи дослідження: описовий метод (для інвентаризації номенклатурних назв і пояснення специфіки їхньої будови й у діахронії, і в синхронії); метод пасивного спостереження (реєстраційний метод) використано для вибірки із широкого загалу саме техноменів автотранспортних засобів, зокрема на позначення автобусної техніки; метод компонентного аналізу використано для виокремлення відонімних і відапелятивних складників номенклатурних назв. Застосування вказаних методів уможливило всебічно проаналізувати номенклатурні знаки на позначення автобусів українського виробництва.

\section{Результати та дискусії}

У попередніх наукових розвідках ми вже здійснили спробу зуніфікувати термінологічний апарат термінознавства, давши власне означення терміна технічний номен - спеціальна ідентифікаційна одиниця термінологічної системи, що називає конкретний одиничний об'єкт, конкретний зразок чи серію предметів масового виробництва й репрезентує номенклатуру певної галузі науково-технічних знань. Також можна додати у формулювання, що техномен є стисненою проекцією дефініції термінологічної одиниці й основних 
технічних характеристик об’єкта науки, що переважно передається власне терміном чи абревіатурою, з додаванням символьної чи цифрової частини або ж онімів. Також зауважуємо, що вводимо в науковий обіг термін номенклатурне моделювання, здефінувавши його як процес віднайдення розробниками найоптимальнішої для поціновувачів автомобільної техніки назви автотранспортного засобу, що адекватно репрезентувала 6 і технічні параметри реалії, і комерційні інтереси виробника.

Пропоноване наразі дослідження проведено на матеріалі сучасних назв світових марок, моделей і модифікацій автобусної техніки, здійснено спробу віднайти й виокремити із загального масиву номенклатури насамперед відонімні моделі номенів українських автовиробників, розглянуто їхню етимологічну специфіку й лінгвокультурологічні аспекти номінування.

Автобусне назовництво в Україні має доволі успішну історію: «Один із перших українських автобусів був побудований на Кам'янець-Подільському чавуноливарному і механічному заводі «Мотор» (1918 рік заснування), оснащеному запчастинами і комплектуючими, що залишилися на гарнізонних інженерних складах ще від царської армії... Поміркувавши над власними можливостями, дирекція кам'янецького заводу прийшла до рішення - спробувати будувати автобуси власної конструкції. Інженери і техніки підприємства в стислі строки (за чотири місяці!) зуміли розробити документацію й налагодити виробництво автобуса, якому дали назву «Кам'янецький мотор». Перший автобус виїхав із заводу напередодні жовтневих свят 1923 року, ще один був зібраний через два місяці» (У Кам’янці...). Отже, назва першого українського автобуса була утворена з огляду на територіальну (географічну) приналежність й офіційну назву заводувиробника: “Кам'янецький мотор» - автобус, виготовлений у місті Кам'янець-Подільський на заводі «Мотор». Причому це той рідкісний для назви автобуса випадок, коли найменування двослівне: сполука «прикметник + іменник».

Надалі в українському автобусному назовництві вказана практика найменування була продовжена, українська топоніміка (зокрема ойконім, потамонім, оронім) неодноразово використовувалися в номенклатурних одиницях на позначення автобусної техніки: автобус ЛАЗ 699 «Україна», автобус ЛАЗ «Украӥна-73», автобус ЛАЗ-699А 
«Карпати», автобус ЛАЗ-699А «Карпати-1», автобус ЛАЗ-695E "Львів», автобус ХАРЗ 5259 «Харків'янин», автобус АСЧ-03 «Чернігівець», автобус АКСМ-01-452Д «Десна-2М», автобус ЛАРЗ-977 «Луганськ», .мікроавтобус «Донбас». Указані моделі автобусів виробництва радянської України довший час курсували дорогами не тільки нашої держави, а й ближнього зарубіжжя. А ось сучасний автобус ЛА3 Lemberg DL теж отримав топонім у назву, однак не кириличного написання, бо Лемберг (нім. Lemberg) - німецькомовна назва міста Львів, що побутувала у два періоди існування обласного центру України: 1772-1918 рр. та 1941-1944 рр..

Що стосується сьогодення автобусобудування на теренах нашої держави, то, на думку науковців від техніки I. В. Кривов’язюка й С. О. Крайчука, наразі найбільш потужними виробниками автобусів в Україні є: АТ «Черкаський автобус», корпорація «Еталон», ПАТ «Завод “Часівоярські автобуси"», ПАТ «Запорізький автомобільний завод», ПАТ «АК “Богдан Моторс” (Кривов’язюк \& Крайчук, 2016: 55).

На особливу увагу в нашому дослідженні заслуговує «Еталон» одна з найбільших корпорацій серед українських виробників автомобільної техніки, до складу якої входить 21 підприємство. У 2018 році побачив світ новий низькопідлоговий автобус корпорації «Еталон», що вже за традицією отримав флористичну назву - автобус міський «Acтра» A12210. У номенклатурному активі концерну маємо ще такі квіткові компоненти в назвах автобусної техніки: автобус приміський «Пролісок» А079.52-30, автобус туристичний «Мальва» A079.53, автобус міжміський «Тюльпан» А08430, автобус міжміський «Троянда» А08123-10, автобус туристичний «Мак» А083.10, автобус міський «Ромашка» A11110, автобус туристичний «Соняшник» A1485, автобус міський А074 «Чорнобривецьь».

Президент корпорації «Еталон» Володимир Бутко так пояснює тяглу традицію автобусного назовництва: «Ми б хотіли, щоб продукція нашого виробництва асоціювалися з чимось українським, приємним і до болю рідним. Тому техніку, що випускається сьогодні підприємствами корпорації, ми назвали іменами квітів, які з дитинства пречудово нам знайомі. Іменами українських квітів» (Автобуси...).

Знаходимо в електронних часописах ще одну цікаву для дослідження інформацію про те, що в липні 2019 року в Україні 
побудували новий український автобус, який отримав номенклатурну назву «Нест». Докладніших технічних характеристик, як і подробиць про його виробника, поки що не повідомляється, однак відомо, що автором проєкту є Юрій Нестерчук, звідси й назва нової машини «Нест» - усічення прізвища Нестерчук (В Україні...).

Подібна прізвищево-номінативна практика в українському автобусному назовництві нами зафіксована вперше, хоча в зарубіжному автопромі це доволі звичне явище: «Бентлі», «Бугатті», «Б'юїк», "Додж», «Кавасакі», «Крайслер», «Ламборліні», «Мазераті», «Майбах», «Міиуока», «Опель», «Пежо», «Порше», «Рено», «Роллс-Ройс», «Сітроен», «Сузукі», «Тойода», «Феррарі», «Форд», «Хонда»- усе це імена засновників або ж конструкторів автотранспортних компаній і концернів.

В українському автобусному назовництві нами в незначній кількості зафіксовано й інші антропонімічні джерела номінації, зокрема особові імена в назвах мають такі автобуси: ХАЗ-3250 «Антон», ХАЗ A-103 «Руслан», ЗАЗ А07А «І-Ван», ГалАЗ-3207 «Вікторія», «Богдан» A-06900 (E-2).

Відапелятивні номени на позначення автобусів не є предметом нашого дослідження в цій статті, однак варто зауважити, що в поданих далі прикладах прослідковуємо вже іншу тенденцію - відхід від використання в номенах української топоніміки й захоплення чужомовною лексикою, однак вона наразі адаптована в українській мові й записана кирилицею: мікроавтобус ЛАСЗ «Старт», автобус ЛАЗ-4207/ «Лайнер-10», автобус ЛАЗ-АХ183 «Аеропорт», автобус ЛАЗ-А183 «Сіmі», автобус ЛАЗ-697М «Турист», автобус Скіф-5204, автобус ТУР А-061, автобус ЛАЗ «Лайнер-12», автобус ЛАЗ-4207DМ «НеоЛАЗ», автобус Рута-35 ТА Турист.

Надалі ще фіксуємо надзвичайно поширену на сьогодення особливість моделювання сучасних автобусних номенів, що полягає у свідомому невикористанні автохтонних найменувань, зокрема в новітніх моделях ЛАЗ AeroLAZ, ЛАЗ CityLAZ-10LE, ЛА3 LinerLAZ, ЛАЗ InterLAZ-13,5LE, ЛАЗ LinerLAZ, Hyundai Bogdan A 201, aвmoбycпозашляховик "Torsus Praetorian», як і в зарубіжному автобусобудуванні, де теж нехтується національна специфіка й надається перевага англомовним назвам: VDL Interliner, BAW Street Line, Mudan MD6750 City bus, Ayats Bravo I City, MAN Lion's City $12 \mathrm{G}$. 


\section{Висновки}

Отже, звисновковуємо: наразі українське автобусне назовництво, переважно полишивши тяглу традицію використання в назвах національно-культурного (націєтворчого) складника, піддається загальносвітовим тенденціям і провадить позанаціональноорієнтовану культурологічну практику в номенклатурному моделюванні номенів автобусної техніки, уживаючи англійські назви на позначення, однак такого типу інтернаціоналізація $є$ типовою для світового ринку автобусобудування.

Перспективи подальших розвідок ми вбачаємо в поглибленому вивченні низки актуальних питань: 1) уточнення типу семантичного компонента відонімних автотранспортних номенів, зв'язку власної назви, асоціативного фактора й позначуваного матеріального об’єкта; 2) класифікація відапелятивних автотранспортних номенів, визначення типів номенклатурного моделювання й різновидів семантичного компонента; 3) типологізація буквено-цифрових складників технічних номенклатурних одиниць на позначення автотранспортної техніки. Указані проблеми надалі потребують додаткової уваги українських термінологів, причому обов’язково в тісній співпраці з представниками досліджуваних технічних галузей.

\section{ЛІТЕРАТУРА}

1. Автобуси корпорації «Еталон»: нові імена. URL: https://www.autocentre.ua/ kommercheskie/novinka-kommercheskie/avtobusy-etalon-novye-imena-140577.html. 2. В Україні випустили новий автобус «Нест». URL: https://www.autocentre.ua/ua/ news/sobytie/v-ukraine-vypustili-novyj-avtobus-nest-894742.html. 3. Кривов'язюк I. В., Крайчук С. О. Аналіз українського ринку автобусобудування та тролейбусобудування. Науковий журнал Луцького національного технічного університету «Економічний форум». 2016. Вип. 2. С. 51-61. 4. Нікуліна Н. В. Відонімні моделі автомобільних номенів (на матеріалі назв японських марок, моделей і модифікацій автотранспортних засобів). Термінологічний вісник: зб. наук. пр. Київ: Ін-т укр. мови НАНУ, 2017. Вип. 4. С. 167-173. 5. Нікуліна Н. В. Палітра автофарбової номенклатури: структура, семантика і практика. Вісник: Проблеми української термінології. Львів: НУ «Львівська політехніка», 2018. № 890. С. 62-66; 6. У Кам’янці зібрали один із перших автомобілів. URL: https://ye.ua/istiriya/U_Kam_yanci_zbirali_odin_iz_pershih_avtomobiliv.htm.

\section{REFERENCES}

1. Avtobusy korporatsiyi «Etalon»: novi imena [«Etalon» corporation buses: new names]. (n.d.). Autocentre.ua. Retrieved from https://www.autocentre.ua/kommercheskie/ novinka-kommercheskie/avtobusy-etalon-novye-imena-140577.html [in Ukrainian]. 
2. V Ukrayini vypustyly novyy avtobus «Nest» [In Ukraine built a new bus «Nest»]. (n.d.). Autocentre.ua. Retrieved from https://www.autocentre.ua/ua/news/sobytie/v-ukrainevypustili-novyj-avtobus-nest-894742.html [in Ukrainian]. 3. Kryvovyazyuk, I. V. \& Kraychuk, S. O. (2016). Analiz ukrayinskoho rynku avtobusobuduvannya ta troleybusobuduvannya [Analysis of the Ukrainian bus and trolley bus market]. Ekonomichnyy forum - Economic forum, 2, 51-61 [in Ukrainian]. 4. Nikulina, N. V. (2017). Vidonimni modeli avtomobilnykh nomeniv (na materiali nazv yaponskykh marok, modeley i modyfikatsiy avtotransportnykh zasobiv) [Denominative models of automobile nomens (on the material of Japanese makes, models and modifications of vehicles)]. Terminolohichnyy visnyk - Terminology Bulletin, 4, 167-173 [in Ukrainian]. 5. Nikulina, N. V. (2018) Palitra avtofarbovoyi nomenklatury: struktura, semantyka i praktyka [Auto-paint nomenclature palette: structure, semantics and practice]. Visnyk NU «Lvivska politekhnika» - Bulletin of Lviv Polytechnic National University, 890, 62-66 [in Ukrainian]; 6. U Kamyantsi zibraly odyn iz pershykh avtomobiliv [In Kamyanci collected one of the first cars]. (n.d.). Ye.ua. Retrieved from https://ye.ua/istiriya/U_Kam_yanci_zbirali_odin_iz_pershih_avtomobiliv.htm [in Ukrainian].

Нікуліна Неля Василівна - кандидат філологічних наук, доцент, завідувач кафедри українознавства, Харківський національний автомобільно-дорожній університет; вул. Ярослава Мудрого, 25, м. Харків, 61002, Україна.

Tel. +38-050-638-93-61

E-mail: nykulina@ukr.net

http://orcid.org/0000-0001-7832-7407

Nikulina Nelia - Ph.D in Philology, Associate Professor, Head of the Ukrainian Studies Department, Kharkiv National Automobile and Highway University; Jaroslava Mudroho Str. 25, Kharkiv, 61000, Ukraine. 